\title{
Mineral and Heavy Metal Composition of Crude Oil Polluted Soil Amended with Non-Ionic Surfactant (Triton X-100) and White Rot Fungus (Pleurotus ostratus)
}

Anacletus FC, Nwauche KT* and Ighorodje-Monago CC

Department of Biochemistry, Faculty of Science, University of Port Harcourt, Choba, Rivers State, Nigeria

\begin{abstract}
The ability of the macro-fungus, Pleurotus ostreatus and non-ionic surfactant (Triton X-100) to degrade crude oil in crude oil polluted soil was investigated with a view to ascertain their efficacy in reducing the toxicity of polluted ecosystem. Crude oil polluted soil samples $(2000 \mathrm{~g})$ contained in polypropylene bags $(20 \mathrm{~cm}$ diameter $\times 20 \mathrm{~cm}$ height $)$ were inoculated with $P$. ostreatus mycelium and triton $\mathrm{x}-100$ and incubated at 28 to $30^{\circ} \mathrm{C}$ for 60 days. Crude oil polluted soil samples were analyzed before inoculation and incubation and they served as the control. In all the heavy metals quantified $(\mathrm{Pb}, \mathrm{Cu}, \mathrm{Mn}, \mathrm{Cd}$ and $\mathrm{Ni})$, there is a significant difference at $P \leq 0.05$ when all the amended cells $(\mathrm{B}$ to $\mathrm{D})$ are compared with the control cell $(\mathrm{A})$. For $\mathrm{Pb}$, the concentration of all the cells amended significantly reduced with cells C (PSS+Triton $x-100)$ having the lowest concentration of $1.52 \pm 0.02$ when compared with the control cell $(11.31 \pm$ 0.15). For $\mathrm{Cu}, \mathrm{Cd}$ and $\mathrm{Ni}$, all the amended cells were seen to be reduced in their concentrations when compared with the concentration of the control sample. For $\mathrm{Mn}$, the concentrations of the amended cells were seen to be high when compared with the concentration of the control sample. For all the mineral elements analyzed ( $\mathrm{Ca}, \mathrm{Mg}, \mathrm{Na}$ and $\mathrm{K})$, there is a significant difference at $P \leq 0.05$ when all the amended cells (B to $D)$ are compared with the control cell (A). For $\mathrm{Ca}$, there was a significant difference $(P \leq 0.05)$ when cell $\mathrm{A}$ is compared with other cells. Highest reduction in $\mathrm{Ca}$ level was seen in cell D (PSS+Pleurotus ostreatus+Triton X-100) with the value of $88.28 \pm 2.72$. For $\mathrm{Mg}$, all the amended cells were seen to have a significant increase in their values when compared with the control sample $(271.15 \pm 0.45)$. For $\mathrm{Na}$ and $\mathrm{K}$, only cell $\mathrm{B}$ had the highest value of $90.18 \pm 0.73$ for $\mathrm{Na}$ and $371.54 \pm 2.26$ for $\mathrm{K}$. Cell $\mathrm{C}$ was observed to be slightly reduced for $\mathrm{Na}$ while cell $\mathrm{C}$ and $\mathrm{D}$ were also seen to be reduced for $\mathrm{K}$. These results showed that white rot fungus ( $P$. ostreatus) and triton $\mathrm{x}-100$ were able to degrade the polluting oil and as such may be suitable for remediating crude oil polluted soil.
\end{abstract}

Keywords: Surfactants; Triton x-100; Pleurotus ostreatus; Pollution and heavy metals

\section{Introduction}

The soil is an essential beneficiary by configuration or mischance of a horde of waste products and chemicals utilized as a part of present day society. Contamination created by petroleum and its subsidiaries is the most pervasive issue in nature. Since business investigation of petroleum began in Nigeria in 1958 [1], petroleum has consistently become pillar of the Nigerian economy. Be that as it may, the investigation of petroleum has prompted the contamination of area and conduits.

The nearness of oil and refined petroleum items in the soil can prompt harmful consequences for plants and soil microorganisms and goes about as a wellspring of ground water sullying [2]. Petroleum hydrocarbon tainting of soil happens through extraction, mischances, pipeline, delights, utilization and refining [3]. The majority of the raw petroleum stores and oil refineries in Nigeria are situated in territories with agrarian exercises and urban zones in the Niger Delta. It is thought by reports, that a normal riverine tenant of the Niger Delta is presented to polluted air, contaminated water and dirtied nourishment, henceforth confronting wellbeing risk coming about to diminished future [4]. Thus, the remediation of soil affected by oil generation and transport is of significance considering ecological issues as well as for the conservation of agrarian efficiency and human wellbeing. Chemical and physical techniques connected with remediation of petroleum-defiled soils, for example, warm treatment, soil washing, hardening and adjustment are costly, problematic to the earth and include high-vitality utilization. In this way, regular remediation strategies have been produced to give all the more naturally friendly and financially savvy cleanup of locales affected by petroleum spills [5].
The exploration of petroleum products has rendered agrarian terrains less profitable [6] and the streams and the amphibian lives have turned out to be pretty much dead [7]. The Niger Delta locale of Nigeria has encountered a few common unrests because of natural corruption from oil investigation [8], in this manner the arrival of raw petroleum into the earth by oil slick is accepting overall consideration.

Different authors Odu et al. [9-13] have reported that the impact of oil spillage on greenery changes relying upon the sum and kind of hydrocarbon involved, the affectability of the species and the topology of the area. Oil spillage could likewise present metals, for example, copper, zinc and lead into the earth which may be dangerous to plants and harm soil biological systems. The main real oil slick that got a lot of open consideration was in 1967 and is prevalently alluded to as the Torrey Canyon oil slick in the English Channel. After the tanker ran on solid land, it discharged around 30000 tons of oil and was left for six weeks before any composed reaction by the authorities concerned, by which time she had released all the oil into the water [14]. A spill of such size was extraordinary thus there was insufficient time to react. The

*Corresponding author: Nwauche KT, Department of Biochemistry, Faculty of Science, University of Port Harcourt, Choba, Rivers State, Nigeria, Tel: +084523613 E-mail: kelechi.nwauche@uniport.edu.ng

Received March 10, 2017; Accepted March 20, 2017; Published April 01, 2017

Citation: Anacletus FC, Nwauche KT, Ighorodje-Monago CC (2017) Mineral and Heavy Metal Composition of Crude Oil Polluted Soil Amended with Non-lonic Surfactant (Triton X-100) and White Rot Fungus (Pleurotus ostratus). J Environ Anal Toxicol 7: 449. doi: 10.4172/2161-0525.1000449

Copyright: () 2017 Anacletus FC, et al. This is an open-access article distributed under the terms of the Creative Commons Attribution License, which permits unrestricted use, distribution, and reproduction in any medium, provided the original author and source are credited. 
Citation: Anacletus FC, Nwauche KT, Ighorodje-Monago CC (2017) Mineral and Heavy Metal Composition of Crude Oil Polluted Soil Amended with Non-Ionic Surfactant (Triton X-100) and White Rot Fungus (Pleurotus ostratus). J Environ Anal Toxicol 7: 449. doi: 10.4172/21610525.1000449

Page 2 of 3

principal dread about the oil discharge needed to do with the style of the shorelines despite the fact that it influenced marine life too.

\section{Materials and Methods}

\section{Collection of soil sample}

The crude oil polluted soil samples used for this experiment were collected from an oil spill site at Ibuocha community, location 1, Ogba/ Egbema/Ndoni L.G.A., Rivers State.

\section{Preparation of culture medium}

The fungus $P$. ostreatus used for this study was obtained from the Mycology unit in the Department of Plant Science and biotechnology, University of Port Harcourt, Choba, Rivers State. The culture was subcultured in malt extract agar to get pure growing culture.

Malt Extract Agar (MEA) was prepared by dissolving $20 \mathrm{~g}$ of agar powder and $20 \mathrm{~g}$ of malt extract broth in $1000 \mathrm{ml}$ of distilled water. The mixture was autoclaved at $121^{\circ} \mathrm{C}$ for $15 \mathrm{~min}$. On cooling to $45^{\circ} \mathrm{C}$, the medium was dispensed into $9 \mathrm{~cm}$ Petri dishes to gel.

\section{Spawn production}

Spawn was prepared following a modified method described by Senyah et al. [15]. The guinea corn (Sorghum bicolor) grains used were thoroughly washed with tap water and soaked overnight. They were dispensed into spawn bottles and autoclaved at $121^{\circ} \mathrm{C}$ for $1 \mathrm{~h}$ each day for three consecutive days. On cooling, the grains in each bottle were inoculated with four $9 \mathrm{~mm}$ mycelia discs taken from a 4-day-old agar culture of $P$. ostreatus and incubated at $28 \pm 2^{\circ} \mathrm{C}$ for 14 days in darkness.

\section{Fungal and surfactant inoculation}

A modified method of Baldrian et al. [16] was employed. $2000 \mathrm{~g}$ aliquots of crude oil polluted soil were weighed into polypropylene bags (20 cm diameter $\times 30 \mathrm{~cm}$ high). Each bag was inoculated with $7 \mathrm{~g}$ of spawn of the test fungus and $3 \mathrm{ml}$ of triton $\mathrm{x}-100$ and were subsequently tied with masking tape. All the bags were incubated at $28 \pm 2^{\circ} \mathrm{C}$ for 60 days. Completely randomized design was used in the experiment.

\section{Determination of exchangeable $\mathrm{Ca}, \mathrm{Mg}$ and $\mathrm{Mg}$ in soil (Black) [17]}

Determination of $\mathrm{Ca}, \mathrm{Na}, \mathrm{K}$ and $\mathrm{Mg}$ : this was carried out using atomic absorption spectrophotometer (AAS). $30 \mathrm{ml}$ of $1 \mathrm{~N} \mathrm{NH}_{4} \mathrm{OAC}$ (Ammonium Acetate) solution was added to $5 \mathrm{~g}$ of oven dried sample soil and shaken for 15 minutes. The supernatant was decanted into 1000 $\mathrm{ml}$ flask. The process above was repeated thrice and the extract solution (i.e., supernatant) was made up to $100 \mathrm{ml}$ by $\mathrm{NH}_{4} \mathrm{O}$ AC solution. From the solution $\mathrm{K}, \mathrm{Na}, \mathrm{Mg}$ and $\mathrm{Ca}$ values were determined using atomic absorption spectrophotometer (AAS).

\section{Determination of heavy metals (US EPA) [18]}

Five grams of air-dried, $2 \mathrm{~mm}$ sieved soil sample was weighed into a $100 \mathrm{ml}$ beaker and $2 \mathrm{ml}$ of $\mathrm{HNO}_{3}$ and $6 \mathrm{ml}$ of $\mathrm{HCl}$ were added into the beaker in the ratio of 1:3. The mixture was digested by heating on a heating mantle to obtain a near-dryness mixture. The digested sample was filtered using distilled water through a filter paper (Whatman No. $42,150 \mathrm{~mm}$ in diameter) into a $50 \mathrm{ml}$ volumetric flask. Distilled water was added to make up to $50 \mathrm{ml}$ mark digested filtrate in the volumetric flask. The digested soil sample was presented to the atomic absorption spectrophotometer and the concentrations of the selected heavy metals were ascertained. The atomic absorption spectrophotometer was calibrated using standard solutions (solutions of known concentration) for each of the selected metals.

\section{Statistical analysis of data}

Experimental data collected were analyzed for statistical differences by means of one-way ANOVA and post hoc LSD, on SPSS 20 to ascertain the level of significant difference between the control and the inoculated samples. In all, $p<0.05$ was considered significant. Data are presented as mean \pm S.D (standard deviation).

\section{Results}

Each value is a mean of three replicates expressed as mean \pm S.D. Values in the same column with common superscript letters $(a, b, \ldots)$ are significantly different at $p \leq 0.05$ when compared with the contaminated soil sample (Table 1).

Each value is a mean of three replicates expressed as mean \pm S.D. Values in the same column with common superscript letters $(a, b, \ldots)$ are significantly different at $p \leq 0.05$ when compared with the contaminated soil sample (Table 2).

\section{Discussion}

Tables 1 and 2 shows the mean $\mathrm{Pb}, \mathrm{Cu}, \mathrm{Mn}, \mathrm{Cd}$ and Ni concentrations and mean $\mathrm{Ca}, \mathrm{Mg}, \mathrm{Na}$ and $\mathrm{K}$ concentrations of crude oil polluted soil sample and the polluted soil samples amended/inoculated with white rot fungus (Pleurotus ostreatus) and non-ionic surfactant (Triton-x-100). For all the mineral elements and heavy metals analyzed, there is a significant difference at $p \leq 0.05$ when all the amended cells (B to D) are compared with the control cell (A).

For $\mathrm{Pb}$, the concentration of all the cells amended significantly decreased with cells $\mathrm{C}$ (CISS+Triton $\mathrm{x}$-100) having the lowest concentration of $1.52 \pm 0.02$ when compared with the control cell (11.31 $\pm 0.15)$. For $\mathrm{Cu}, \mathrm{Cd}$ and $\mathrm{Ni}$, all the amended cells were seen to be reduced in their concentrations when compared with the concentration of the control sample. For Mn, the concentrations of the amended cells were seen to be high when compared with the concentration of the control sample.

The effect of the amendments on the mineral elements shows that the Mg level increased significantly when the amended cells are compared with the control cell. $\mathrm{Na}$ and $\mathrm{K}$ levels was also observed to have increased significantly across the column except for cell $\mathrm{C}$ (CISS+Triton $\mathrm{x}$-100) that had a slight decrease when compared with the control cell. This observation is attributed to the fact that crude oil pollution adversely affects the soil ecosystem through adsorption to soil particles and provision of an excess carbon that might be unavailable for microbial use.

Heavy metal content at the end of the investigation were significantly decreased in all the amended cells when compared to the untreated cell. However, manganese values were observed to be slightly higher in all the amended cells when compared with the control cell. The significant reduction observed in the heavy metal content especially for cells $B$ and $\mathrm{D}$ is an indication that $P$. ostreatus has accumulated the heavy metals present in the soil. This may be due to the fact that the salts of these metals are soluble and are eventually assimilated by microbes. Siegel et al. and Kalac et al. $[19,20]$ reported that fungi have ability to accumulate metals from the environment and have also found relevance in the treatment of heavy metals. The effect of the surfactant used (triton $\mathrm{x}$-100) when compared with amendment materials was observed to have efficiently and significantly cleaned up the soil and provided a 
Citation: Anacletus FC, Nwauche KT, Ighorodje-Monago CC (2017) Mineral and Heavy Metal Composition of Crude Oil Polluted Soil Amended with Non-Ionic Surfactant (Triton X-100) and White Rot Fungus (Pleurotus ostratus). J Environ Anal Toxicol 7: 449. doi: 10.4172/21610525.1000449

Page 3 of 3

\begin{tabular}{|c|c|c|c|c|c|}
\hline Cell & Treatment & $\mathrm{Ca}(\mathrm{mg} / \mathrm{kg})$ & $M g(\mathbf{m g} / \mathbf{k g})$ & $\mathrm{Na}(\mathbf{m g} / \mathbf{k g})$ & $\mathrm{K}(\mathrm{mg} / \mathrm{kg})$ \\
\hline A & Crude oil impacted soil sample (CISS) & $291.30 \pm 1.06^{a}$ & $271.15 \pm 0.45^{a}$ & $44.53 \pm 0.45^{\mathrm{a}}$ & $315.83 \pm 1.43^{a}$ \\
\hline B & CISS+Pleurotus ostreatus & $99.32 \pm 0.82^{\mathrm{a}}$ & $299.87 \pm 1.42^{\mathrm{a}}$ & $90.18 \pm 0.73^{a}$ & $371.54 \pm 2.26^{\mathrm{a}}$ \\
\hline C & CISS+Triton $\mathrm{x}-100$ & $260.18 \pm 0.96^{a}$ & $327.10 \pm 0.78^{a}$ & $42.37 \pm 0.66^{a}$ & $277.32 \pm 2.59^{a}$ \\
\hline D & CISS + Pleurotus ostreatus+Triton $x-100$ & $88.28 \pm 2.72^{\mathrm{a}}$ & $299.32 \pm 0.71^{a}$ & $60.44 \pm 0.78^{a}$ & $359.59 \pm 1.42^{\mathrm{a}}$ \\
\hline
\end{tabular}

Table 1: Effect of amendments on selected soil mineral elements.

\begin{tabular}{|c|c|c|c|c|c|c|}
\hline Cell & Treatment & $\mathrm{Pb}$ (mg/kg) & $\mathrm{Cu}(\mathrm{mg} / \mathrm{kg})$ & Mn (mg/kg) & $\mathrm{Cd}(\mathrm{mg} / \mathrm{kg})$ & $\mathrm{Ni}(\mathrm{mg} / \mathrm{kg})$ \\
\hline A & $\begin{array}{l}\text { Crude oil Impacted soil sample } \\
\text { (CISS) }\end{array}$ & $11.31 \pm 0.15^{\mathrm{a}}$ & $5.81 \pm 0.02^{\mathrm{a}}$ & $52.07 \pm 0.24^{\mathrm{a}}$ & $0.79 \pm 0.04^{a}$ & $2.89 \pm 0.03^{a}$ \\
\hline B & CISS+Pleurotus ostreatus & $5.56 \pm 4.47^{a}$ & $4.17 \pm 0.02^{\mathrm{a}}$ & $55.29 \pm 0.34^{\mathrm{a}}$ & $0.19 \pm 0.00^{\mathrm{a}}$ & $1.82 \pm 0.06^{a}$ \\
\hline C & CISS+Triton $x-100$ & $1.52 \pm 0.02^{\mathrm{a}}$ & $3.32 \pm 0.01^{\mathrm{a}}$ & $56.51 \pm 0.36^{a}$ & $\mathrm{BDL}^{\mathrm{a}}$ & $1.16 \pm 0.02^{\mathrm{a}}$ \\
\hline D & $\begin{array}{c}\text { CISS+Pleurotus ostreatus+Triton } \\
x-100\end{array}$ & $6.34 \pm 0.03^{\mathrm{a}}$ & $3.16 \pm 0.01^{\mathrm{a}}$ & $81.68 \pm 1.03^{\mathrm{a}}$ & $\mathrm{BDL}^{\mathrm{a}}$ & $1.11 \pm 0.03^{\mathrm{a}}$ \\
\hline
\end{tabular}

Table 2: Effect of amendments on Soil Heavy Metals.

suitable condition for microbial growth during the experiment which stimulated the reduction of the heavy metal content of the polluted soil at the low concentration applied. Efroymson et al. [21,22] reports indicated that addition of Triton $\mathrm{x}-100$ at a concentration greater than its CMC (critical micelle concentration) inhibited adhesion of bacteria to solid surface, which in turn prevented the degradation of both hexadecane and naphthalene.

\section{References}

1. Okoh Al (2003) Biodegradation of Bonny light crude oil in soil microcosm by some bacteria strains isolated from crude oil flow stations saver pits in Nigeria. African Journal of Biotechnology 2: 104-108.

2. Scott SL (2003) Biodegradion and Toxicity of Total Petroleum Hydrocarbon Leachate from Land Treatment Units. Department of Engineering, California Polytechnic State University, p: 52.

3. United Nations (UN) Report (2001) Protecting Ecosystem for people and planet. United Nations Environmental Programme. pp: 130-147.

4. Alkorta I, Garbisu C (2001) Phytoremediation of organic contaminants in soils. Bioresour Technol 79: 273-276.

5. Dabbs WC (1996) Oil Production and Environmental Damage.

6. Okpokwasili GC, Odokuma LO (1990) Effect of salinity on Biodegradation of oil spills dispersants. Waste Management 10: 141-146.

7. Odokuma LO, Inor MN (2002) Nitrogen fixing bacteria enhanced bioremediation of crude oil polluted soil. Global Journal of Pure and Applied Science 8: 455468.

8. Inoni OE, Omotor DG, Adun FN (2006) The effect of oil spillage on crop yield and farm income in Delta State, Nigeria. Journal of Central European Agriculture 7: 41-49.

9. Odu CT (1978) The effect of nutrient application and aeration on oil degradation in soil. Environmental Pollution 15: 235-240.

10. Anoliefo GO, Vwioko DE (1995) Effects of spent lubricating oil on the growth of Capsicum annum L. and Lycopersicon esculentum Miller. Environmental Pollution 88: 361-364.

11. Ekundayo EO, Obuekwe O (2000) Effects of an Oil Spill on Soil PhysicoChemical Properties of a Spill Site in a Typic Udipsamment of the Niger Delta Basin of Nigeria. Environmental Monitoring and Assessment 60: 235-249.

12. Ouédraogo E, Mando A, Zombré NP (2001) Use of compost to improve soil properties and crop productivity under low input agricultural system in West Africa. Agriculture, Ecosystems \& Environment 84: 259-266.

13. Bernal MP, Alburquerque JA, Moral R (2009) Composting of animal manures and chemical criteria for compost maturity assessment. A review. Bioresource Technology 100: 5444-5453.

14. Burrows $P$, Rowley C, Owen D (1974) The economics of accidental oil pollution by tankers in coastal waters. Journal of Public Economics 3: 251-268.

15. Senyah J, Robinson R, Smith J (1989) The cultivation of the oyster mushroom
Pleurotus ostreatus (Jacq.Ex.Fr.) Kummer on cocoa shell waste. Mushroom science 2: 207-217.

16. Pesciaroli L, Petruccioli M, Fedi S, Firrincieli A, Federici F, et al. (2000) Characterization of Pleurotus ostreatus Biofilms by using the Calgary biofilm device. Applied and Environmental Microbiology 72: 1132-1140.

17. Black CA (1965) Methods of Soil Analysis. Agronomy. American Society of Agronomy, Madison, Wisconsin.

18. United State Environmental Protection Agency (USEPA) (1996) Method 8015B Non halogenated Organics using GC/FID, Revision 2.

19. Siegel SM, Galun M, Siegel BZ (1990) Filamentous fungi as metal bioadsorbents. A review. Water, Air and Soil Pollution 53: 335-334.

20. Kalac P, Niznanska M, Bevilaqua D, Staskova I (1996) Concentration of Mercury, Copper, Cadmium and Lead in fruiting bodies of edible Mushrooms in the vicinity of a mercury smelter and a copper smelter. Science of the Total Environment 177: 251.

21. Efroymson RA, Alexander M (1991) Biodegradation by an Arthrobacter species of hydrocarbons partitioned into an organic solvent. Applied and Environmental Microbiology 57: 1441-1447.

22. Ortega-Calvo JJ, Alexander M (1994) Roles of bacterial attachment and spontancous partitioning of naphthalene initially present in non-aqueous phase liquids. Applied and Environmental Microbiology 60: 2643-2646. 